\title{
Risk Factors Associated with Linkage to Care among Suburban Hepatitis C-Positive Baby Boomers and Injection Drug Users
}

\author{
Audun J. Lier - Kalie Smith · Kerim Odekon - Silvia Bronson • \\ Erin Taub • Mathew Tharakan · Gerald J. Kelly • Pruthvi Patel • \\ Luis A. Marcos
}

Received: April 1, 2019 / Published online: May 25, 2019

(C) The Author(s) 2019

\section{ABSTRACT}

Introduction: Suffolk County, located in Eastern Long Island, has been an epicenter for the opioid epidemic in New York State, yet no studies have examined hepatitis $\mathrm{C}$ virus (HCV) prevalence in this population. Additionally, few studies have assessed barriers for linkage to care (LTC) to HCV treatment in people who inject drugs (PWID), a high-risk HCV cohort. We

Enhanced Digital Features To view enhanced digital features for this article go to https://doi.org/10.6084/ m9.figshare. 8125025 .

A. J. Lier $(\varangle) \cdot$ K. Odekon $\cdot$ E. Taub $\cdot$ M. Tharakan Department of Internal Medicine, Stony Brook University Hospital, New York, USA

e-mail: Audun.Lier@stonybrookmedicine.edu

K. Smith · S. Bronson · L. A. Marcos

Division of Infectious Diseases, Department of Internal Medicine, Stony Brook University Hospital, New York, USA

G. J. Kelly

Division of Family and Community Medicine, Department of Family, Population and Preventive Medicine, Stony Brook University Hospital, New York, USA

P. Patel

Division of Gastroenterology, Department of Internal Medicine, Stony Brook University Hospital, New York, USA aimed to determine prevalence of HCV infection in a suburban medical center and to assess risk factors associated with LTC in HCV-positive baby boomers and young PWID.

Methods: A retrospective chart review was carried out on adult patients with ICD-9/10 diagnostic codes for HCV from January 2016 to December 2018 at Stony Brook Medicine. Data collected included sociodemographics, RNA serostatus, LTC, health insurance, employment, past medical or psychiatric history, and substance or injection drug use.

Results: Overall, 27,049 individuals were screened for HCV and 1017 were HCV seropositive (3.8\%), 437 (42.9\%) were HCV RNA-positive and $153(40.6 \%)$ achieved LTC. In multivariate analysis, living with cirrhosis was associated with a positive LTC. Medicaid or Medicare insurance was associated with a negative LTC. Intravenous drug users were more likely to be young and have concomitant polysubstance use and psychiatric disease. A bimodal distribution of $\mathrm{HCV}$-positives is present in our population.

Conclusion: Those with liver cirrhosis are more likely to achieve LTC, as are those with private insurance. Public health efforts to promote awareness of $\mathrm{HCV}$ and to facilitate access to treatment among PWID are needed.

Keywords: Hepatitis C virus; Intravenous drug abuse; Linkage to care; Risk factors 


\section{INTRODUCTION}

Hepatitis C virus (HCV) is the etiology of the most common bloodborne infection in the United States (US) [1] and can lead to significant comorbidities such as cirrhosis and hepatocellular carcinoma [2]. Deaths from HCV between 2003 and 2013 surpassed those from 60 other nationally notifiable infectious conditions, including those from human immunodeficiency virus (HIV) [3]. HCV burden of cases in the US is estimated at 5 million, many of whom are asymptomatic and unaware they are infected [4].

It has been identified that baby boomersthose born between 1945 and 1965-constitute approximately three-quarters of all HCV antibody-positive cases. This finding led to the institution of a grade B recommendation by the United States Preventive Services Task Force for a one-time HCV screening of all baby boomers [5], and the enactment of the Hepatitis Testing Law in New York State [6]. However, recent reports indicate a rising prevalence of $\mathrm{HCV}$ in persons who inject drugs (PWID) among younger, non-urban populations $[7,8]$.

Numerous studies in nonurban areas have identified injection drug use as the most common risk factor for HCV transmission [9-11] and that a longer duration of injection drug use is associated with higher infection risk [12]. In Massachusetts, the distribution of HCV by age was found to have drastically changed from a unimodal model focused on baby boomers to bimodal with an additional peak centered on young persons in their 20s or 30s [13]. Thus, not only is HCV becoming more common in PWID but also in persons born after 1965 .

While several studies have concluded PWID and young adults are associated with a higher risk of HCV infection in nonurban areas, to our knowledge, there are far fewer studies that assess the barriers to linkage to care (LTC) in these particular cohorts. The majority of studies reporting on LTC focus on baby boomers and often conclude risk factors to primarily be lack of insurance and being of certain races or ethnicities [14-18]. As Stony Brook Medicine (SBM) is the only tertiary medical center in suburban Suffolk County, New York (NY) [19] and serves a population of approximately 1.6 million persons, we aimed to: (1) determine the prevalence of HCV in the SBM cohort; (2) identify risk factors for LTC in both the baby boomer cohort and those born in other years; and (3) identify specific risk factors within the PWID cohort.

\section{METHODS}

\section{Study Design}

A retrospective study was designed to identify cases of HCV diagnosed at SBM between January 1, 2016 and December 31, 2018. SBM comprises a 603-bed tertiary care hospital, a 125-bed hospital in Southampton, as well as over 90 community-based healthcare settings throughout Suffolk County, NY. The electronic health system primarily used for both inpatient and outpatient care is the Cerner Electronic Health Record System (EHRS) (Cerner, Kansas City, MO, USA).

\section{Search Criteria}

The total number of patients tested were extracted from SBM inpatient, emergency department, and outpatient clinic visits with the assistance of Stony Brook Information Technology services. HCV antibody-positives were identified via EHRS search with diagnostic codes ICD-9: 070.54 (Chronic hepatitis C without mention of hepatic coma) and ICD-10: B18.2 (Chronic viral hepatitis C).

\section{Case Definitions}

Eligible patients for this study included those (1) 18 years and older, and (2) diagnosed with a positive HCV antibody test. Baby boomer was defined as birth year between 1945 and 1965 . LTC requires a positive RNA result and was defined as attending an outpatient appointment in which the physician addressed HCV management. Patients incapable of LTC included RNA-positives who declined LTC, were deceased/terminally ill, or were determined to already be in care (a known diagnosis already 
following with a physician specifically for the disease). The adjusted LTC subtracts those incapable of LTC from the denominator.

\section{Data Collection}

The following data were obtained from each patient's chart: date of admission or outpatient encounter, age, gender, race, ethnicity, place of birth, zip code of residence, insurance, marital status, occupational status, injection drug use/ history of substance use, psychiatric disease, hepatitis B virus and HIV serostatus, number of comorbid medical conditions, liver function, radiologic imaging, stage of fibrosis, and $\mathrm{HCV}$ genotype. Race/ethnicity were collected from the EHRS and were self-reported by the patient upon presentation to SBM. Race was divided into the following categories: Native American or Alaska native, Asian, black or African American, native Hawaiian or other Pacific Islander, white, or other/declined to specify. Possible ethnicities were Hispanic and non-Hispanic. Data were collected and stored on a shared network drive with password protection.

\section{Statistical Analysis}

Univariate and multivariate analyses were used for the RNA-positive population only, with linkage to care as the outcome variable. Additionally, univariate and multivariate analyses were conducted for RNA-positive PWID, with IV drug use as the outcome variable. Odds ratios (OR) and confidence intervals (CI) were calculated for the above analyses. A map of $\mathrm{HCV}$ antibody-positive cases was created using Tableau Software (Seattle, WA, USA) to visualize geographic clusters of HCV by zip code, adjusted for population density by zip code according to 2010 national census data. A $p$ value of $\leq 0.05$ was considered statistically significant for all tests. Data were analyzed with SAS v.9.4 (SAS Institute, Cary, NC, USA).

\section{Compliance with Ethics Guidelines}

This project was reviewed and approved by the Institutional Review Board (IRB) at SBM, IRB
\#1033821, who waived the requirement for informed consent. This study was performed in accordance with the Helsinki Declaration of 1964 and its later amendments. As data were collected utilizing a retrospective chart review and placed into a deidentified patient database, harm was minimized and patient consent for study participation was therefore not obtained.

\section{RESULTS}

\section{Demographics}

The median age of the total population $(n=1017)$ was 59 years, of which $604(59.4 \%)$ were male and $788(81.5 \%)$ were Caucasian (Table 1). Medicaid (350; 35.7\%) and Medicare $(348 ; 35.5 \%)$ were the two commonest insurance types. Baby boomers composed of $61.8 \%$ (628 cases), while 338 persons were born after 1965 (33.2\%) and 51 born before 1945 (5.0\%). Of the 338 persons born after 1965, $176(52.1 \%)$ were 35 years or younger and $118(67.0 \%)$ of those were PWID. A bimodal distribution with two peaks was created from all antibody-positive cases, one peak centered on baby boomers and the other on young adults (Fig. 1).

\section{Clinical-Epidemiological Features}

A total of 27,119 patients were tested for HCV between 2016 and 2018. Of these, 1017 had a positive antibody test for HCV for a seroprevalence of $3.8 \%, 437$ (42.9\%) tested RNA-positive (HCV RNA prevalence of 1.6\%) (60 patients were incapable of LTC for a total of 377 cases included in our analysis), 153 (40.6\%) were LTC and $53(34.6 \%)$ were started on direct acting antiretroviral (DAA) therapy (Fig. 2a). An RNA test was not completed for 88 antibody-positives. The median length of time for LTC was 57 days (IQR: 26-126).

Regarding only the PWID population born after 1965, there were $187 \mathrm{HCV}$ antibody-positives and 126 (75.4\%) RNA-positives (18 cases who were incapable of LTC for a total of 108 cases included in our analysis). Of the RNApositives, $30(27.8 \%)$ were LTC and $12(40.0 \%)$ 
Table 1 Demographic characteristics of those who were HCV antibody-positive as well as the subgroup of RNA-positives who presented to SBM between 2016 and 2018

\begin{tabular}{|c|c|c|}
\hline Characteristics & $\begin{array}{l}\text { Count }(\%) \\
n=1017 \text { (total population) }\end{array}$ & $\begin{array}{l}\text { Count (\%) } \\
n=437(\text { RNA + only) }\end{array}$ \\
\hline \multicolumn{3}{|l|}{ Age } \\
\hline Median (IQR) & $59(22)$ & $56(28)$ \\
\hline \multicolumn{3}{|l|}{ Gender } \\
\hline Male & $604(59.39)$ & $265(60.64)$ \\
\hline Female & $413(40.61)$ & $172(39.36)$ \\
\hline \multicolumn{3}{|l|}{$\operatorname{Race}^{\mathrm{a}}$} \\
\hline White & $788(81.49)$ & $329(79.28)$ \\
\hline Black & $103(10.65)$ & $56(13.49)$ \\
\hline Asian & $22(2.28)$ & $8(1.93)$ \\
\hline Other & $54(5.58)$ & $22(5.30)$ \\
\hline \multicolumn{3}{|l|}{ Ethnicity $^{\mathrm{a}}$} \\
\hline Non-Hispanic & 872 (91.79) & $373(91.87)$ \\
\hline Hispanic & $78(8.21)$ & $33(8.13)$ \\
\hline \multicolumn{3}{|l|}{ Insurance $^{a}$} \\
\hline Private & $205(20.92)$ & $73(17.18)$ \\
\hline Medicare & $348(35.51)$ & $131(30.82)$ \\
\hline Medicaid & $350(35.71)$ & $190(44.71)$ \\
\hline Self-pay & $69(7.04)$ & $30(7.06)$ \\
\hline V.A & $8(0.82)$ & $1(0.24)$ \\
\hline
\end{tabular}

${ }^{a}$ Sum may not equal total due to missing data

were started on DAA therapy (Fig. 2b). Twenty individuals did not have an RNA test conducted. Regarding this cohort, the median length of time for LTC was 40.5 days (IQR 27.25-136.5).

\section{Risk Factors}

The HCV antibody- and RNA-positive population was assessed for risk factors to LTC. In a multivariate analysis among RNA-positive cases only, excluding people incapable of LTC, when controlling for polysubstance use, cirrhosis, chronic kidney disease, marital status, primary care physician, and being a baby boomer, those who had Medicare (OR 0.29, CI 0.13-0.63, $p=0.002)$ or Medicaid (0.45, CI 0.22-0.90, $p=0.02$ ) had lower odds of LTC than those with private insurance. Conversely, those who had cirrhosis (OR 2.87, CI 1.41-5.84, $p=0.004$ ) had higher odds of LTC than those with no cirrhosis (Table 2).

HCV-positive RNA cases were further stratified among those born after 1965 . When comparing PWID (187 total HCV antibody cases) and non-PWID (79 total HCV antibody cases), several significant risk factors were found (Table 3). A multivariate analysis of PWID born 


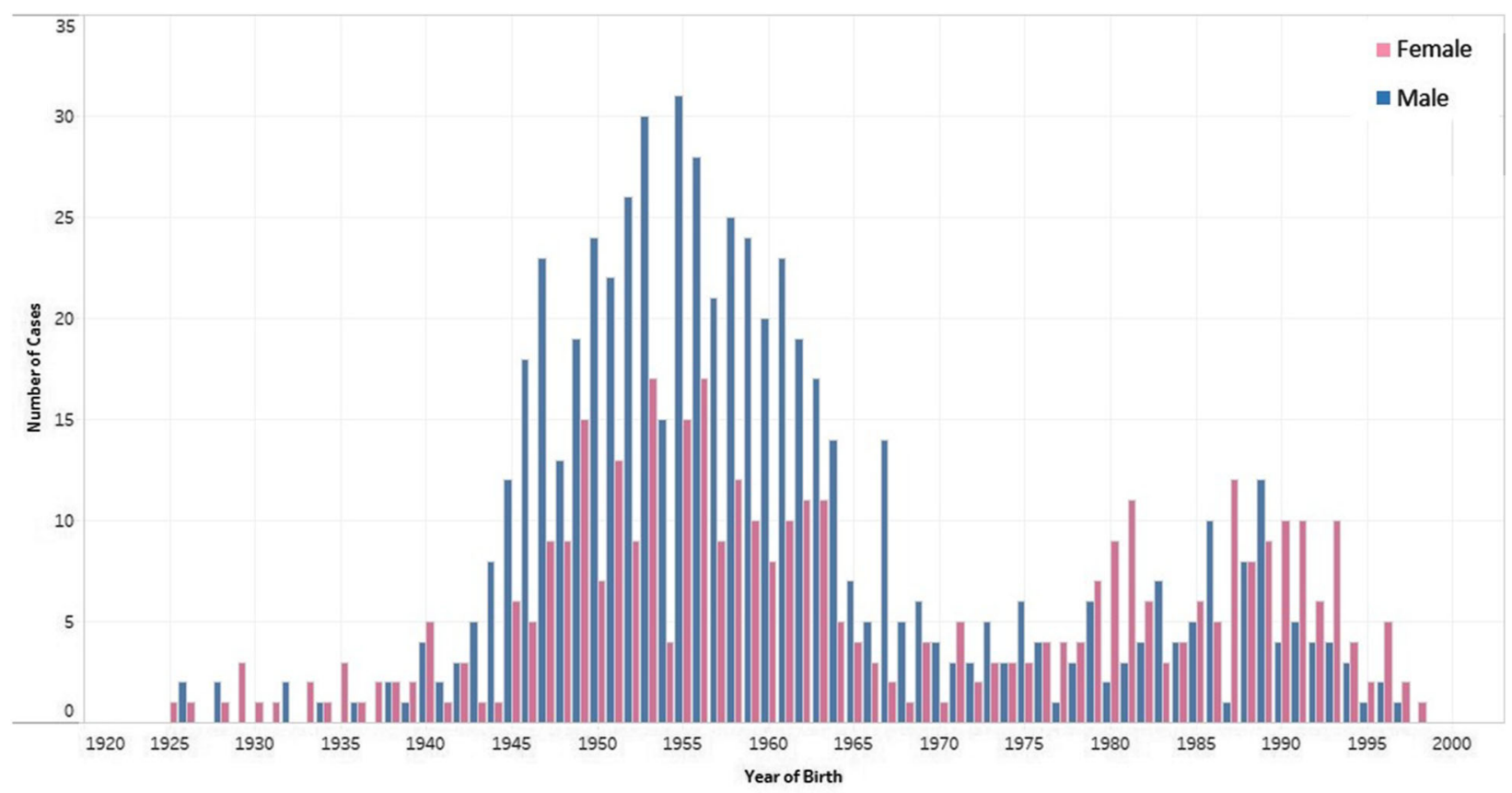

Fig. 1 Bimodal distribution of HCV antibody-positives presenting to Stony Brook Medicine between 2016 and 2018

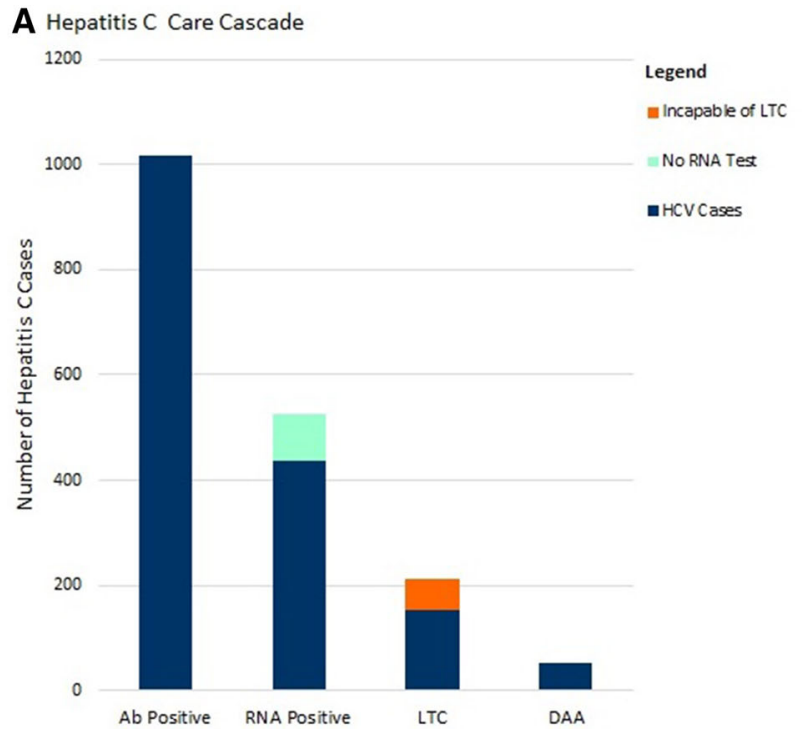

Fig. 2 a HCV Care Cascade at Stony Brook Medicine for all HCV antibody $(A b)$-positives between 2016 and 2018. b HCV Care Cascade at Stony Brook Medicine for all

after 1965, after controlling for number of comorbidities, race, ethnicity, insurance, tobacco use, polysubstance use, marital status, psychiatric disease, and primary care physician found that older age (OR 0.92, CI 0.86-0.98,

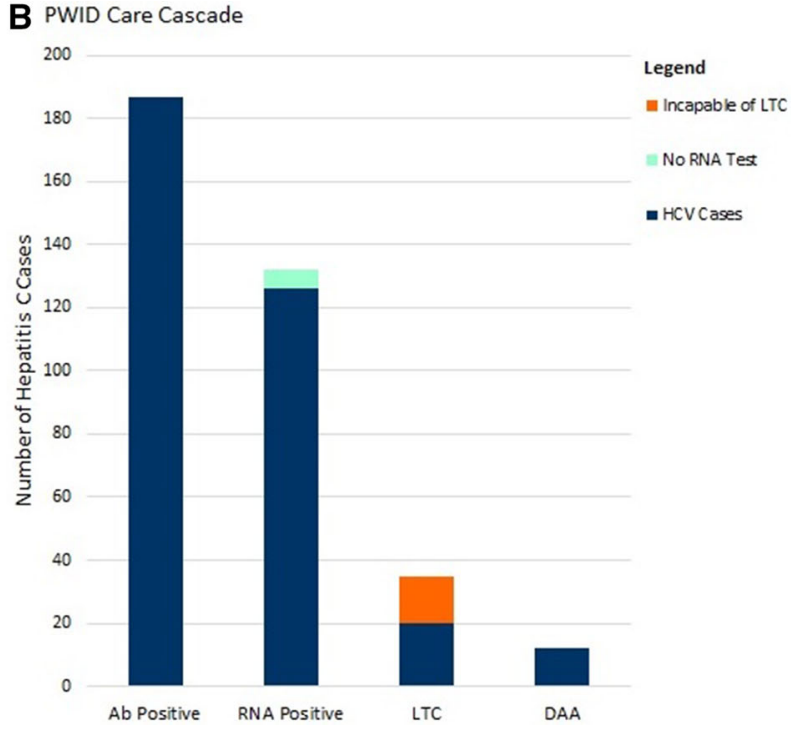

HCV antibody ( $A b)$-positives who identified as PWID between 2016 and 2018

$p=0.01$ ) and being African American (OR 0.09, CI $0.01-0.60, p=0.01$ ) were associated with lower odds of IV drug use (Table 3). Conversely, polysubstance use (OR 73.13, CI 13.09-408.51, $p<0.0001)$ and psychiatric disease (OR 2.79, CI 
Table 2 Multivariate analysis of factors associated with linkage to care (LTC) among HCV antibody-and RNA-positive individuals presenting to SBM

\begin{tabular}{lll}
\hline$n=308$ & $\begin{array}{l}\text { Probability of linking to care } \\
\text { OR (CI) }\end{array}$ & $\boldsymbol{p}$ value \\
\hline Insurance & & 0.002 \\
Medicare vs. private & $0.29(0.13-0.63)$ & 0.024 \\
Medicaid vs. private & $0.45(0.22-0.90)$ & 0.559 \\
Self-pay vs. private & $0.70(0.22-2.29)$ & 0.160 \\
Polysubstance use & & 0.004 \\
Yes vs. no & $0.60(0.29-1.23)$ & 0.163 \\
Cirrhosis & & \\
Yes vs. no & $2.87(1.41-5.84)$ & 0.385 \\
Chronic kidney disease & & 0.629 \\
Yes vs. no & $1.55(0.84-2.89)$ & 0.466 \\
Marital status & & 0.599 \\
Single vs. married/domestic partner & $1.33(0.70-2.51)$ & 0.152 \\
Divorced/separated vs. married/domestic partner & $0.81(0.35-1.89)$ & \\
Widowed vs. married/domestic partner & $0.67(0.23-1.95)$ & \\
Primary care physician & $1.54(0.85-2.76)$ & \\
Yes vs. no & & \\
Baby boomer & & \\
Yes vs. no & & \\
\hline
\end{tabular}

1.09-7.15, $p=0.03$ ) had higher odds of IV drug use.

\section{"Hot spots" or High Incidence Areas of HCV Cases}

Zip codes for every HCV antibody-positive case were mapped in order to assess the high incidence areas of HCV on Long Island (Fig. 3), and were population adjusted according to 2010 national census data. The locations of Stony Brook University Hospital (SBUH) and Southampton Hospital ( $\mathrm{SHH})$ are indicated on the map. The most populous zip code for HCVpositive antibody is located approximately 50 miles east of Stony Brook University Hospital. Other populous zip codes are located in central and southern Suffolk County, NY.

\section{DISCUSSION}

The HCV RNA prevalence (1.6\%) found in this study is approximately 1.7 times higher than the estimated national prevalence of $0.93 \%$, and 2.1 times higher than the estimated New York State (NYS) prevalence of $0.75 \%$ [20]. HCV was most commonly found among baby boomers; however, among non-boomers, the most common HCV-positives were young (less than 35 years), white, non-Hispanics. These findings mirror a new trend of HCV acquisition among young (adolescents and young adults, aged 15-24), white, non-Hispanics living in urban, suburban and rural locations [21]. Additionally, the high HCV prevalence in Suffolk County coincides with its high opioid burden (opioid overdose deaths, non-fatal ED visits and 
Table 3 Multivariate sub-analysis of factors associated with intravenous drug use among HCV antibody and RNA-positive PWID at Stony Brook Medicine between 2016 and 2018

\begin{tabular}{lccc}
\hline $\boldsymbol{n}=\mathbf{2 0 2}$ & Probability of IV drug use OR (CI) & $P$ value \\
\hline Age & $0.92(0.86-0.98)$ & 0.01
\end{tabular}

Number of comorbidities

$\geq 4$ vs. $<4$

$2.22(0.46-10.66)$

Race

Black vs. white

$\begin{array}{cc}0.09(0.01-0.60) & 0.01 \\ <0.001(<0.001->999.9) & 0.99 \\ 0.54(0.02-19.07) & 0.74\end{array}$

Asian vs. white

Other vs. white

$$
0.54(0.02-19.07)
$$

Ethnicity

Hispanic vs. non-Hispanic

$0.27(0.02-4.10)$

Insurance

Medicare vs. private

$1.21(0.17-8.48)$

Medicaid vs. private

$1.76(0.51-6.11)$

Self-pay vs. private

$0.57(0.06-5.79)$

Tobacco

Yes vs. no

$0.83(0.28-2.08)$

Polysubstance use

Yes vs. no

Marital status

Married/domestic partner vs. single

$0.34(0.10-1.14)$

0.08

Divorced/separated vs. single

$0.53(0.09-3.13)$

0.49

Widowed vs. single

$>999.9(<0.001->999.9)$

Psychiatric disease

Yes vs. no

Primary care physician

Yes vs. no

$0.61(0.25-1.52)$

hospital discharges involving opioid use disorder), ranking in the top quartile of all counties in NYS [22].

When HCV cases were graphed by age of diagnosis and gender, we found a bimodal distribution with baby boomers and young adults as the two major cohorts. The baby boomers show a higher amount of male cases, while females and males are in similar numbers in the younger cohort. Although data from this study support $\mathrm{HCV}$ affecting equal numbers of males and females, female PWID may be more exposed to $\mathrm{HCV}$ due to riskier injection drug practices [23]. Current and future public health awareness efforts should address female injection drug practices.

Our HCV care cascade mirrors the national $\mathrm{HCV}$ care continuum, where the largest gaps in 


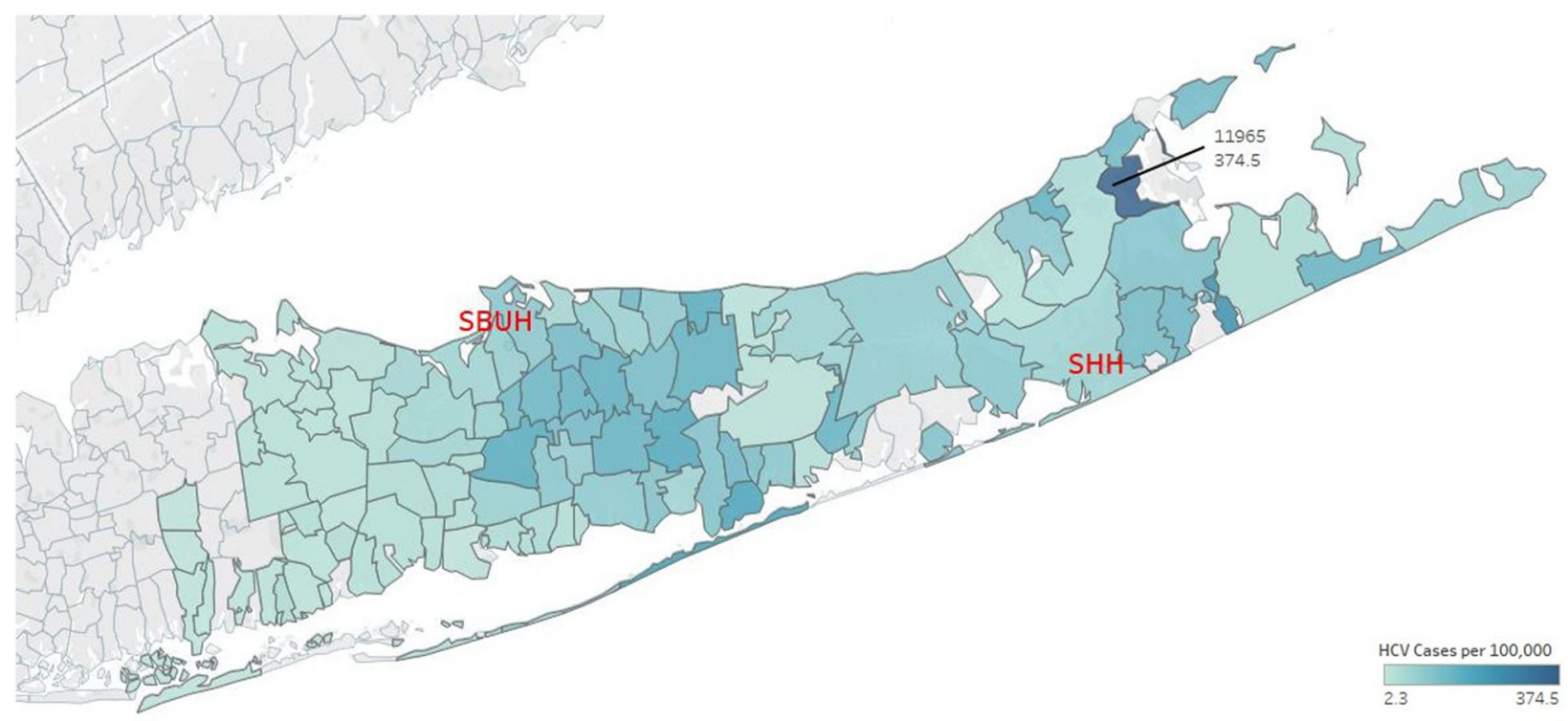

Fig. 3 HCV antibody-positives between 2016 and 2018 living in Suffolk County, NY, mapped by zip code. Stony Brook University Hospital $(S B U H)$ and Southampton Hospital $(S H H)$ are indicated on the map

care occur first between HCV RNA confirmatory testing and attendance at first appointment (LTC), then between LTC and initiation of direct acting antiviral (DAA) therapy. LTC was $40.6 \%$ in our study, lower than other integrated health systems that utilize best practice interventions and patient navigators $[14,15,17,18]$. We found that $34.6 \%$ of those LTC began DAA therapy, which is higher than in some studies [24-26] but not others [27]. Whether this rate was due to our patients linking early or that greater than $90 \%$ of our patients had insurance is unclear. However, it must be noted that due to our low LTC, there was not a large cohort to assess for initiation or completion of DAA therapy. Among PWID, 27.8\% achieved LTC, lower than reported elsewhere [27, 28]. However, $40 \%$ were started on DAA therapy, which is higher than that found in other reports [27].

Our length of time from diagnosis to date of LTC was comparatively shorter than LTC timelines reported elsewhere [26, 29]. Studies indicate that most individuals achieve LTC within the first 6 months of diagnosis [30], and the majority of our LTC occurred within this time frame. This LTC timeline may simply be transient during the time period observed. Further stratification of the length of time until LTC may explain this occurrence by indicating the LTC time frames for different cohorts, perhaps by age, insurance type, or drug use.

In our multivariate analysis of all $\mathrm{HCV}$ and RNA-positives, being a baby boomer and having a diagnosis of cirrhosis is associated with higher odds of LTC. Baby boomers overall have limited knowledge about the necessity of HCV screening [31]. Thus, like carrying a diagnosis of cirrhosis and chronic kidney disease (multimorbidity domains), once diagnosed with HCV they may be more motivated to attend an appointment with a specialist to seek care due to perception of illness in the setting of other age-related comorbidities. This multimorbidity hypothesis has been stated in a previous study [29]. In contrast, polysubstance use was not associated with decreased LTC. Previous studies in suburban locations have identified young injection drug users as associated with decreased linkage to care [8]. However, our multivariate analysis did not substratify injection drug use and its association with LTC. Having Medicaid as an insurance carrier was found to be associated with decreased LTC, a finding reported in multiple studies $[24,29,32,33]$. According to NYS Medicaid law in March 2018, in an attempt to increase access 
to $\mathrm{HCV}$ treatment, there is no longer a requirement to be an $\mathrm{HCV}$-experienced provider in order to treat patients [34]. This law aims to increase the number of programs meant to connect New York residents in high-risk communities with comprehensive HCV prevention, screening, and treatment. Thus, our decreased LTC is a failure of the care cascade, rather than of public policy.

In a multivariate analysis of those born after 1965, PWID were significantly more likely to be younger, white, and have concomitant polysubstance and psychiatric disease. Although we did not assess for LTC in this subpopulation, there is reason to believe that this is a vulnerable population with which the healthcare community would have difficulty with connecting to DAA therapy. Previous studies show that barriers to LTC and treatment include lack of trust with healthcare providers [35], misconceptions regarding treatment adherence [36] as well as higher rates of depression and psychiatric illness [37]. Injection drug use is also a common reason for treatment deferral due to factors such as deteriorating financial status, decline in personal health status, less access to healthcare resources, and higher financial burden [38]. However, a recent investigation in rural Kentucky found that PWID achieved LTC in their community (59\%) but were not accessing subsequent treatment [39]. According to a survey of $\mathrm{HCV}$ prescribers at the American Association for the Study of Liver Diseases (AASLD) Liver Meeting in 2014, only 15\% of clinicians stated they would treat an active PWID (last injection within 30 days) with DAAs, citing reinfection and cost as the most impactful concerns [40]. However, AASLD guidelines from 2018 explicitly state "recent or active [injection drug use] should not be seen as an absolute contraindication to HCV therapy. [...] Scaling up HCV treatment in persons who inject drugs is necessary to positively impact the HCV epidemic in the US [41]." Further interventions are clearly needed to decrease the stigma surrounding treatment of this population.

Analysis of zip codes of HCV-positive patients shows numerous hot spots of $\mathrm{HCV}$ infection, with the most populous zip code located in Eastern Long Island, approximately
50 miles from Stony Brook Hospital. To our knowledge, these are the first data demonstrating the presence of clusters of HCV antibodypositive individuals in Suffolk County, NY. The distant eastern zip code cluster is a compelling finding, given that the other most populous zip codes are in close proximity to SBM. With further expansion of SBM to eastern Long Island through Stony Brook Southampton Hospital, Southampton, NY, the results may vary in location or by cohort as more results from eastern Suffolk County will be collected.

Suffolk County, and possibly the rest of Long Island, is facing an HCV epidemic; detection of HCV RNA prevalence was 1.7 times higher than the national average and 2.1 times higher than the previously reported state average. As the majority of non-boomers (55.3\%) were known PWID, it is vital to initiate timely interventions to both decrease the spread of HCV and increase the LTC for those already affected by the disease. It has been shown that harm reduction interventions, early detection and treatment, and special attention to social barriers may all help in drastically reducing the number of $\mathrm{HCV}$ infections in this cohort [42, 43]. We suggest point of care testing for $\mathrm{HCV}$ antibody with reflex RNA as well as prompt linkage to care to start DAA with the assistance of patient navigators and concomitant referral to substance use treatment centers.

Our study had a few limitations. First, our study was a retrospective chart review. As a result, we did not have longitudinal information to determine how many patients have achieved a sustained virologic response. Second, although our time to appointment is much less than national data, which may be because the majority of our population was insured, and thus may not be generalizable to urban or rural areas where the proportion of uninsured may be higher.

\section{CONCLUSION}

In conclusion, a higher prevalence of HCV was found in Suffolk County than other locations in New York State and we have identified a new cohort of young HCV-positives who are less 
likely to be linked to care compared with their older counterparts. Further interventions are urgently needed to increase the linkage to care in this younger population in order to prevent long-term health sequelae and to reduce the risk of HCV transmission.

\section{ACKNOWLEDGEMENTS}

We thank the participants of the study.

Funding. No funding or sponsorship was received for this study or publication of this article. The article processing charges were funded by the authors.

Authorship. All named authors meet the International Committee of Medical Journal Editors (ICMJE) criteria for authorship for this article, take responsibility for the integrity of the work as a whole, and have given their approval for this version to be published.

Disclosures. Pruthvi Patel and Luis A. Marcos have received a grant from FOCUS (Gilead Sciences, Inc.). Luis A. Marcos has participated as an advisor for Gilead and has received consultation fees from Gilead. Audun J. Lier, Kalie Smith, Kerim Odekon, Silvia Bronson, Erin Taub, Mathew Tharakan and Gerald J. Kelly do not have any conflicts of interest to declare. FOCUS funding supports HIV, HCV, and hepatitis b virus (HBV) screening and linkage to the first medical appointment after diagnosis.

Compliance with Ethics Guidelines. This project was reviewed and approved by the Institutional Review Board (IRB) at SBM, IRB \#1033821, who waived the requirement for informed consent. This study was performed in accordance with the Helsinki Declaration of 1964 and its later amendments. As data were collected utilizing a retrospective chart review and placed into a deidentified patient database, harm was minimized and patient consent for study participation was therefore not obtained.

Data Availability. The datasets generated during and/or analyzed during the current study are available from the corresponding author on reasonable request.

Open Access. This article is distributed under the terms of the Creative Commons Attribution-NonCommercial 4.0 International License (http://creativecommons.org/licenses/ by-nc/4.0/), which permits any noncommercial use, distribution, and reproduction in any medium, provided you give appropriate credit to the original author(s) and the source, provide a link to the Creative Commons license, and indicate if changes were made.

\section{REFERENCES}

1. Alter MJ, Kruszon-Moran D, Nainan OV, McQuillan GM, Gao F, Moyer LA, et al. The prevalence of hepatitis $\mathrm{C}$ virus infection in the United States, 1988 through 1994. N Engl J Med. 1999;341(8):556-62. https://doi.org/10.1056/ NEJM199908193410802.

2. Lozano R, Naghavi M, Foreman K, Lim S, Shibuya K, Aboyans V, et al. Global and regional mortality from 235 causes of death for 20 age groups in 1990 and 2010: a systematic analysis for the Global Burden of Disease Study 2010. Lancet. 2012;380(9859):2095-128. https://doi.org/10.1016/ S0140-6736(12)61728-0.

3. Ly KN, Hughes EM, Jiles RB, Holmberg SD. Rising mortality associated with hepatitis $C$ virus in the United States, 2003-2013. Clin Infect Dis. 2016;62(10):1287-8. https://doi.org/10.1093/cid/ ciw111.

4. Chak E, Talal AH, Sherman KE, Schiff ER, Saab S. Hepatitis $C$ virus infection in USA: an estimate of true prevalence. Liver Int. 2011;31(8):1090-101. https://doi.org/10.1111/j.1478-3231.2011.02494.x.

5. Moyer VA, Force USPST. Screening for hepatitis C virus infection in adults: U.S. Preventive Services Task Force recommendation statement. Ann Intern Med. 2013;159(5):349-57. https://doi.org/10.7326/ 0003-4819-159-5-201309030-00672.

6. New York State Department of Health. Hepatitis C testing law: provider fact sheet. http://www.health. ny.gov/publications/1820.pdf, 2014. Accessed 21 May 2018.

7. Suryaprasad AG, White JZ, Xu F, Eichler BA, Hamilton J, Patel A, et al. Emerging epidemic of hepatitis $\mathrm{C}$ virus infections among young nonurban 
persons who inject drugs in the United States, 2006-2012. Clin Infect Dis. 2014;59(10):1411-9. https://doi.org/10.1093/cid/ciu643 (Epub 2014 Aug 11).

8. Akyar E, Seneca KH, Akyar S, Schofield N, Schwartz MP, Nahass RG. Linkage to care for suburban heroin users with hepatitis $C$ virus infection, New Jersey, USA. Emerg Infect Dis. 2016;22(5):907-9. https:// doi.org/10.3201/eid2205.151980.

9. Zibbell JE, Iqbal K, Patel RC, Suryaprasad A, Sanders $\mathrm{KJ}$, Moore-Moravian L, et al. Increases in hepatitis C virus infection related to injection drug use among persons aged $</=30$ years-Kentucky, Tennessee, Virginia, and West Virginia, 2006-2012. Morb Mortal Wkly Rep. 2015;64(17):453-8.

10. Havens JR, Lofwall MR, Frost SD, Oser CB, Leukefeld CG, Crosby RA. Individual and network factors associated with prevalent hepatitis C infection among rural Appalachian injection drug users. Am J Public Health. 2013;103(1):e44-52. https://doi.org/ 10.2105/AJPH.2012.300874.

11. El-Ghitany EM, Abdel Wahab MM, Abd El-Wahab EW, Hassouna S, Farghaly AG. A comprehensive hepatitis $\mathrm{C}$ virus risk factors meta-analysis (1989-2013): do they differ in Egypt? Liver Int. 2015;35(2):489-501. https://doi.org/10.1111/liv. 12617.

12. Akselrod H, Grau LE, Barbour R, Heimer R. Seroprevalence of $\mathrm{HIV}$, hepatitis $\mathrm{B}$ virus, and $\mathrm{HCV}$ among injection drug users in Connecticut: understanding infection and coinfection risks in a nonurban population. Am J Public Health. 2014;104(9):1713-21. https://doi.org/10.2105/ AJPH.2013.301357.

13. Kim AY, Onofrey S, Church DR. An epidemiologic update on hepatitis $C$ infection in persons living with or at risk of HIV infection. J Infect Dis. 2013;207(Suppl 1):S1-6. https://doi.org/10.1093/ infdis/jis927.

14. Turner BJ, Taylor BS, Hanson JT, Perez ME, Hernandez L, Villarreal R, et al. Implementing hospitalbased baby boomer hepatitis $C$ virus screening and linkage to care: Strategies, results, and costs. J Hosp Med. 2015;10(8):510-6. https://doi.org/10.1002/ jhm.2376.

15. Rodriguez $\mathrm{CV}$, Rubenstein $\mathrm{KB}, \mathrm{Hu} \mathrm{H}$, Linas $\mathrm{BP}$, Horberg M. Hepatitis $C$ virus infection and increasing screening and linkage to care in a large integrated health system. J Patient Cent Res Rev. 2016;3:177. https://doi.org/10.1097/PHH.000000 0000000466 .

16. Levin JM, Huckins E. Integration healthcare system implementation of one time hepatitis $\mathrm{C}$ virus testing for patients born between 1945 and 1965 with linkage to care. J Hepatol. 2017;66:489-90.

17. Miller LS, Rollin F, Fluker SA, Lundberg KL, Park B, Quairoli K, et al. High-yield birth-cohort hepatitis C virus screening and linkage to care among underserved African Americans, Atlanta, Georgia, 2012-2013. Public Health Rep. 2016;131(Suppl 2):84-90. https://doi.org/10.1177/0033354916131 0S213.

18. Castrejon M, Chew KW, Javanbakht M, Humphries $\mathrm{R}$, Saab S, Klausner JD. Implementation of a large system-wide hepatitis $C$ virus screening and linkage to care program for baby boomers. Open Forum Infect Dis. 2017;4(3):ofx109. https://doi.org/10. 1093/ofid/ofx109.

19. Department of Health and Human Services, Centers for Medicare and Medicaid Services. Medicare Program; Medicare Prescription Discount Card. https:// www.cms.gov/Regulations-and-Guidance/Regulati ons-and-Policies/QuarterlyProviderUpdates/down loads/cms4063ifc.pdf, 2003. Accessed 20 Feb 2019.

20. Rosenberg ES, Rosenthal EM, Hall EW, Barker L, Hofmeister MG, Sullivan PS, Dietz P, Mermin J, Ryerson AB. Prevalence of hepatitis $C$ virus infection in US states and the district of Columbia, 2013 to 2016. JAMA Netw Open. 2018;1(8):e186371. https://doi.org/10.1093/cid/cix202.

21. Centers for Disease Control and Prevention. Hepatitis $C$ virus infection among adolescents and young adults: Massachusetts, 2002-2009. Morb Mortal Wkly Rep. 2011;60(17):537-41.

22. New York State Department of Health. New York State Opioid Annual Data Report 2018. https:// www.health.ny.gov/statistics/opioid/data/pdf/nys opioid_annual_report_2018.pdf, 2018. Accessed 29 Apr 2019.

23. Tracy D, Hahn JA, Fuller Lewis C, Evans J, Briceno A, Morris MD, et al. Higher risk of incident hepatitis $\mathrm{C}$ virus among young women who inject drugs compared with young men in association with sexual relationships: a prospective analysis from the UFO Study cohort. BMJ Open. 2014;4(5):e004988. https://doi.org/10.1136/bmjopen-2014-004988.

24. Bourgi K, Brar I, Baker-Genaw K. Health disparities in hepatitis $\mathrm{C}$ screening and linkage to care at an integrated health system in Southeast Michigan. PLoS ONE. 2016;11(8):e0161241. https://doi.org/ 10.1371/journal.pone.0161241.

25. Maier MM, Ross DB, Chartier M, Belperio PS, Backus LI. Cascade of care for hepatitis $C$ virus infection within the US veterans health administration. Am J Public Health. 2016;106(2):353-8. https://doi.org/ 10.2105/AJPH.2015.302927. 
26. Anderson ES, Galbraith JW, Deering LJ, Pfeil SK, Todorovic T, Rodgers JB, et al. Continuum of care for hepatitis $\mathrm{C}$ virus among patients diagnosed in the emergency department setting. Clin Infect Dis. 2017;64(11):1540-6. https://doi.org/10.1093/cid/ cix163.

27. Moore MS, Bocour A, Laraque F, Winters A. A surveillance-based hepatitis C care cascade, New York City, 2017. Public Health Rep. 2018;133(4): 497-501. https://doi.org/10.1177/00333549187766 41.

28. Mohamed Z, Rwegasha J, Kim JU, Shimakawa Y, Poiteau L, Chevaliez S, Bhagani S, Taylor-Robinson S, Thursz MR, Mbwambo J, Lemoine M. The hepatitis $\mathrm{C}$ cascade of care in people who inject drugs in Dar es Salaam, Tanzania. J Viral Hepat. 2018;25(12):1438-45. https://doi.org/10.1111/jvh. 12966.

29. Franco RA, Overton ET, Tamhane AR, Forsythe JM, Rodgers JB, Schexnayder JK, et al. Characterizing failure to establish hepatitis $\mathrm{C}$ care of baby boomers diagnosed in the emergency department. Open Forum Infect Dis. 2016;3(4):ofw211. https://doi. org/10.1093/ofid/ofw211.

30. White DA, Anderson ES, Pfeil SK, Trivedi TK, Alter HJ. Results of a rapid hepatitis $C$ virus screening and diagnostic testing program in an urban emergency department. Ann Emerg Med. 2016;67(1):119-28. https://doi.org/10.1016/j.annemergmed.2015.06. 023 .

31. Allison WE, Chiang W, Rubin A, Oshva L, Carmody E. Knowledge about hepatitis $C$ virus infection and acceptability of testing in the 1945-1965 birth cohort (baby boomers) presenting to a large urban emergency department: a pilot study. J Emerg Med. 2016;50(6):825-31. https://doi.org/10.1016/j.jemer med.2016.02.001.

32. Tohme RA, Xing J, Liao Y, Holmberg SD. Hepatitis $\mathrm{C}$ testing, infection, and linkage to care among racial and ethnic minorities in the United States, 2009-2010. Am J Public Health. 2013;103(1):112-9. https://doi.org/10.2105/AJPH.2012.300858.

33. Assomou SA, Huang W, Horsburgh Jr CR, Drainoni M-L, Linas BP. Relationship between hepatitis C clinical testing site and linkage to care. Open Forum Infect Dis. 2014;1(1):ofu009. https://doi.org/10. 1093/ofid/ofu009.

34. New York State Department of Health. Revision in Hepatitis C Prescriber Requirements. https:// hepfree.nyc/nys-medicaid-update-removal-of-thehcv-prescriber-experience-clinical-criteria, 2018. Accessed 21 Feb 2019.
35. Treloar C, Rance J, Backmund M. Understanding barriers to hepatitis $C$ virus care and stigmatization from a social perspective. Clin Infect Dis. 2013;57(Suppl 2):S51-5. https://doi.org/10.1093/ cid/cit263.

36. Aspinall EJ, Corson S, Doyle JS, Grebely J, Hutchinson SJ, Dore GJ, et al. Treatment of hepatitis $\mathrm{C}$ virus infection among people who are actively injecting drugs: a systematic review and meta-analysis. Clin Infect Dis. 2013;57(Suppl 2):S80-9. https://doi.org/10.1093/cid/cit306.

37. Schaefer M, Sarkar R, Diez-Quevedo C. Management of mental health problems prior to and during treatment of hepatitis $\mathrm{C}$ virus infection in patients with drug addiction. Clin Infect Dis. 2013;57(Suppl 2):S111-7. https://doi.org/10.1093/ cid/cit266.

38. Souliotis K, Agapidaki E, Papageorgiou M, Voudouri $\mathrm{N}$, Contiades X. Access to treatment for Hepatitis C among injection drug users: results from the crosssectional HOPE IV study. Int J Equity Health. 2017;16(1):101. https://doi.org/10.1186/s12939017-0601-3.

39. Stephens DB, Young AM, Havens JR. Healthcare contact and treatment uptake following hepatitis $\mathrm{C}$ virus screening and counseling among rural Appalachian people who use drugs. Int J Drug Pol. 2017;47:86-94. https://doi.org/10.1016/j.drugpo. 2017.05.045.

40. Asher AK, Portillo CJ, Cooper BA, Dawson-Rose C, Vlahov D. Clinicians' views of hepatitis $C$ virus treatment candidacy with direct-acting antiviral regimens for people who inject drugs. Subst Use Misuse. 2016;51(9):1218-23. https://doi.org/10. 3109/10826084.2016.1161054.

41. American Association for the Study of Liver Diseases. HCV guidance: recommendations for testing, managing, and treating hepatitis C [Internet]. 2017 [cited 23 May 2018]. https://www.hcvguidelines. org/evaluate/when-whom.

42. MacArthur GJ, van Velzen E, Palmateer N, Kimber J, Pharris A, Hope V, et al. Interventions to prevent HIV and Hepatitis C in people who inject drugs: a review of reviews to assess evidence of effectiveness. Int J Drug Policy. 2014;25(1):34-52. https://doi.org/ 10.1016/j.drugpo.2013.07.001.

43. Grebely J, Matthews GV, Lloyd AR, Dore GJ. Elimination of hepatitis $C$ virus infection among people who inject drugs through treatment as prevention: feasibility and future requirements. Clin Infect Dis. 2013;57(7):1014-20. https://doi.org/10.1093/cid/ cit377. 